\title{
Ancient sedimentary DNA reveals past tsunami deposits
}

Witold Szczucińskia*, Joanna Pawłowska ${ }^{\mathrm{b}}$, Franck Lejzerowicz ${ }^{\mathrm{c}}$, Yuichi Nishimura ${ }^{\mathrm{d}}$, Mikołaj Kokociński $^{\mathrm{e}}$, Wojciech Majewski ${ }^{\mathrm{f}}$, Yugo Nakamura $^{\mathrm{d}, \mathrm{g}}$, Jan Pawlowski $^{\mathrm{c}}$

${ }^{a}$ Institute of Geology, Adam Mickiewicz University in Poznan, Maków Polnych 16, 61-606 Poznań, Poland. email: witek@amu.edu.pl

${ }^{\mathrm{b}}$ Institute of Oceanology, Polish Academy of Sciences, 81-712 Sopot, Poland. email: pawlowska@iopan.gda.pl

${ }^{\mathrm{c}}$ Department of Genetics and Evolution, University of Geneva, 1211 Genève 4, Switzerland. email: Franck.Lejzerowicz@unige.ch, Jan.Pawlowski@unige.ch

${ }^{\mathrm{d}}$ Institute of Seismology and Volcanology, Faculty of Science, Hokkaido University, N10W8 Kita-ku Sapporo, Hokkaido 060-0810, Japan. email: yns@ mail.sci.hokudai.ac.jp

${ }^{\mathrm{e}}$ Department of Hydrobiology, Adam Mickiewicz University in Poznan, Umultowska 89, 61614 Poznań, Poland. email: kok@ amu.edu.pl

${ }^{\mathrm{f}}$ Institute of Paleobiology, Polish Academy of Sciences, 00-818 Warszawa, Poland. email: wmaj@twarda.pan.pl

g Muroto Geopark Promotion Committee, 1810-2 Murotomisaki-cho, Muroto, Kochi 7817101 Japan. email: nakamura@muroto-geo.jp

* Corresponding author: witek@amu.edu.pl

\begin{abstract}
Palaeotsunami deposits are the primary sources of information on past large tsunami events and thereby are critical for earthquake and tsunami hazard assessments. They usually form sandy layers preserved in coastal sediments and contain indicators of marine origins, such as
\end{abstract}


microfossils (e.g., diatoms and foraminifera) and geochemical signals of saltwater. However, these indicators are often modified or erased with time. To address this issue, we present the first application of a palaeogenetic approach to a series of up to approximately 2000-year-old sandy palaeotsunami deposits from a coastal wetland on Hokkaido Island (Japan). We found the DNA of marine foraminiferal species preserved in palaeotsunami deposits, in the absence of foraminifera tests. The recovery and analysis of the ancient sedimentary DNA of marine organisms preserved in coastal zone sediments for millennia represents a new and promising tool for the identification of past tsunamis.

Keywords: palaeotsunami, foraminiferal DNA, palaeogenomics, tsunami, coastal sediments, Japan

\section{Introduction}

During the last two decades, large tsunamis have appeared to be the most dramatic natural disasters worldwide. The tsunamis of December 26th, 2004 in the Indian Ocean and March 11th, 2011 offshore of Japan caused natural catastrophes with the greatest recorded numbers of victims and economic losses, respectively. The magnitudes of these events were unprecedented, since historical records of such large tsunamis are missing or incomplete and are thus insufficient for reliable hazard assessments. Therefore, the only method to extend the history of past large tsunamis is to investigate geological records. Hitherto, the most effective studies have investigated the onshore palaeotsunami deposits, which may indicate the minimum extent of the flooded areas, water depths and velocities of past inundations, as well as may be used to infer the properties of the tsunami-generating earthquakes (e.g., Jaffe and Gelfenbaum, 2007; Sugawara et al., 2012). However, that important information can be inferred only if the palaeotsunami deposits are correctly identified and well preserved. 
The identification of palaeotsunami deposits is often difficult because they comprise of various sediment types that may be similar to other deposits, depend on local sediment sources and are altered by post-depositional processes. There is no simple universal diagnostic set of criteria that can be applied to interpret tsunami deposits with absolute certainty (Morton et al., 2007; Goff et al., 2012). The classical approach relies on the identification of a sedimentary event layer, which is usually coarse-grained, marked by sharp lower contact and contains microfossils of marine origin, such as diatoms and foraminifera (e.g., Pilarczyk et al., 2014; Dura et al., 2016), or geochemical signals of saltwater (ChaguéGoff, 2010). However, these indicators may be erased with time (e.g., Szczuciński, 2012). Thus, there is a need for new indicators that are more resistant to post-depositional alterations. Marine sediments contain considerable amounts of extra-cellular DNA molecules preserved in organic or inorganic aggregates or adsorbed on mineral surfaces (Torti et al., 2015). Although this DNA is affected by degradation, it has been shown that a part of it can be preserved for long periods of time (Coolen and Overmann, 2007; Randlett et al., 2014). Recent advances in palaeogenetic studies (Rawlence et al., 2014; Pedersen et al., 2015) suggest that DNA remnants of marine organisms can be applied not only in environments where the preservation of DNA is favoured by the lack of oxygen or low temperatures (e.g., Coolen et al., 2004) but also in more unstable settings, such as well-oxygenated deep-sea sediments exposed to bioturbation (Coolen et al., 2013; Lejzerowicz et al., 2013). Coastal environments are characterised by highly variable conditions and thus could be considered unlikely to preserve ancient sedimentary DNA. However, modern beach sediments have been shown to contain abundant extracellular DNA adsorbed to silicate-rich sand (Naviaux et al., 2005). Moreover, microbial DNA appeared to be present in recent and c. 600 years old tsunami deposits left on land (Somboonna et al., 2014). Therefore, we hypothesise that the 
molecular imprints of indicatory marine taxa (e.g., foraminifera) could be preserved in palaeotsunami deposits.

Herein we apply the palaeogenetic approach on a series of palaeotsunami deposits from a wetland on eastern Hokkaido Island, Japan. The primary goal of our study is to test if ancient foraminiferal DNA is preserved for long periods in potentially unfavourable coastal wetland environment and if it can be used to identify palaeotsunami deposits.

\section{Study area and methods}

We studied sediments in a natural coastal wetland nearby Urahoro on the Pacific coast of Hokkaido Island, Japan (Fig. 1). This coast was rarely struck by historical typhoons and no large storm flooding events have been reported (Nanayama et al., 2007). However, the previous studies of sedimentary records from this coast have revealed presence of two historical and at least fifteen palaeotsunami layers during the last 5,500 years (Nanayama et al., 2003, 2007; Sawai et al., 2009). Here we present the stratigraphy of an approximately 300-m-long, shore-perpendicular transect of 16 approximately $1 \mathrm{~m}$-long Geoslicer sediment cores across the wetland, which is separated from a wide sandy beach by a belt of coastal dunes (Fig. 1), composed mainly of medium sand.

For laboratory analyses, a ca. $1.5 \mathrm{~m}$-long sediment core (HC) was retrieved and sampled in the field. Seven samples from palaeotsunami sandy layers and from intercalating peat layers were carefully taken from the inner part of the core. Moreover, three additional samples were taken from the surface of the sandy beach and the wetland. Rigorous measures relevant to the ancient DNA research were deployed to avoid contamination; gloves were worn at all times and changed for the handling of every sample, and the core was sampled with sterile, disposable spoons. The samples were directly stored in a cooler and kept frozen at $-20^{\circ} \mathrm{C}$ upon arrival at the laboratory. Additional 14 samples were taken from tephra layers. 
The grain size analysis was conducted on organic matter-free samples sieved through a $0 \Phi(1 \mathrm{~mm})$ sieve. The finer fraction $(>0 \Phi)$ was analysed with a Malvern Mastersizer 2000 Particle Analyser. The data are presented as volume \% and the grain size statistics were calculated using the logarithmic method of moments. The organic matter content is determined as loss on ignition (LOI) at $550{ }^{\circ} \mathrm{C}$.

The samples taken for micropalaeontological analyses of foraminifera were wet washed on a $63-\mu \mathrm{m}$ sieve and subsequently dry-sieved on 125,300 , and $500 \mu \mathrm{m}$ sieves, and analysed under a Nikon SMZ1000 stereomicroscope. The diatoms were analysed following standard methods (Battarbee, 1986). The diatom species were identified under a light microscope with Nomarski contrast at 1000x magnification and following reference books (Lange-Bertalot, 2000; Hofmann et al., 2011). Their classification followed the references listed in Dura et al. (2016). At least 300 diatom valves were identified and counted in most samples. The diatom slides were also checked for radiolaria.

The total DNA content was extracted from approximately $5 \mathrm{~g}$ of sediment using a PowerMax Soil DNA extraction kit (MoBio). All the extractions and polymerase chain reactions (PCRs) were performed in separated, dedicated rooms remote from any post-PCR working area. The number of samples processed during an extraction session was limited to two plus one blank extraction control (without sediment) to reduce the chances for crosscontamination and to monitor potential contamination events. Every PCR session was prepared in a dedicated hood and included one blank PCR control (without template DNA). The short foraminiferal-specific $37 f$ hypervariable region (68-196 bp) of the small subunit ribosomal RNA gene (SSU rDNA) was targeted using the 8-base tagged primers s14F1 and s15 following methods presented by Lejzerowicz et al. (2014), except that 60 PCR cycles were applied. For each sample, 9 PCR replicates were realised using different tagged primer combinations designed following the recommendations of Esling et al. (2015). The positive 
PCR products were quantified using a Qubit fluorometer (Invitrogen) pooled in equimolar quantities, and the pool was then purified using a High Pure PCR Cleanup Micro Kit (Roche). One library was prepared from the pool of PCR products based on a TruSeq Nano DNA Library Preparation Kit (Illumina), which involves an additional PCR step of 8 cycles. The library then was sequenced on an Illumina MiSeq instrument (University of Geneva, Switzerland) for a paired-end run of 150 cycles twice. The raw sequencing data were processed following Pochon et al. (2015), including sequence quality filtering (except that a minimum quality of 30 was required), tagged primer matching ( 2 errors allowed in the primers and 1 in the tags) for sample demultiplexing according to the multiplexing design (Supplementary Table 1), counting and filtering of the mistagging events as in Esling et al. (2015), paired-end read assembly, primer trimming, strict dereplication into unique sequences, and filtering of the unique sequences associated with fewer than 10 read occurrences in a sample. The raw sequence data can be downloaded from the NCBI's Short Read Archive under BioProject PRJNA314674.

The tephra samples were washed and sieved to separate the volcanic glass in grain size fraction $0.063 \mathrm{~mm}$ to $0.125 \mathrm{~mm}$. The glass was analysed for the major element composition using an energy dispersive X-ray spectrometer (EDS, JSM-5310, JEOL). The tephra layers were correlated to known marker tephras (Machida and Arai, 2003; Nakamura, 2016) on the basis of their thickness, stratigraphic position, grain size and volcanic glass geochemistry.

\section{Results}

The sedimentary sequence is comprised of peat deposits intercalated by five sandy layers (T1 - T5) and four tephra layers (Fig. 2). The peat contains about $40 \%$ organic matter and its mineral components are classified as sandy mud (Fig. 3 and Supplementary Table 2). The observed tephras are correlated to marker tephras in eastern Hokkaido (Fig. 2b). The two 
youngest ash layers are identified as the Ko-c2 tephra from the eruption of the Komagatake volcano in 1694 AD that overlies the Ta-b tephra from the 1667 AD Tarumae volcano (Fig. 1b). The next thin ash layer (B-Tm) comes from the $10^{\text {th }}$-century AD eruption of the Baegdusan volcano located in southern China. The oldest tephra is Ta-c, which comes from the Tarumae volcano eruption of approximately 2500 to 2800 calibrated years BP.

The sand units are present as three continuous sand layers traced in all the sediment cores (T1 - T3) and two more layers found only in the deepest parts of the longest cores (T4 and T5). All of the sand layers are characterised by sharp lower and upper contacts. The youngest two units reveal thinning landward from 34 and $16 \mathrm{~cm}$, respectively, for T1 and T2 to only few $\mathrm{cm}$ at the landward end of the transect (Fig. 2a). The older layers are up to $10 \mathrm{~cm}$ thick and reveal smaller variability. The sandy layers contain 5 to $27 \%$ very coarse sand and gravel fraction $(<0 \Phi)$. The coarsest is the T1 layer, which exhibits at least two moderately sorted sub-units that fine upward. The studied sandy deposits contain 1 to $4 \%$ of organic matter and are coarser and more poorly sorted than present beach deposits (Supplementary Table 2).

The analysed samples contain only small amounts of diatom frustules and lack fossilised tests of foraminifera and radiolaria. Altogether, 172 diatom species have been identified (Supplementary Table 3). The modern beach samples are very poor in diatom frustules (Fig. 3). They contain 48 to $60 \%$ of marine diatoms. Diatoms in the modern and fossil peats consisted of $95.5 \%$ to $100 \%$ freshwater species. The diatom content in the sandy layers is generally low, with the lowest number in samples HC3 and HC7. These samples are also characterised by the highest content of brackish and marine species, which reach 19 and $38 \%$, respectively. In the sandy units, we identified 104 species; however, they are represented usually by a few frustules. The most common species in the sand layers are not represented in the local peat and beach deposits. 
The PCR amplification revealed the presence of foraminiferal DNA sequences in all of the modern samples and in most of the ancient deposits (Fig. 3). The next-generation sequencing (NGS) of positive PCR amplification products generated a total of 1,003,752 sequence reads. After filtering 351,731 foraminiferal sequences remained. These sequences were clustered into 25 molecular operational taxonomic units (MOTUs), the majority of which (17) were assigned to non-fossilised monothalamous taxa (Supplementary Table 4). The remaining MOTUs represent the orders Rotaliida and Miliolida.

The modern beach deposits reveal 16 MOTUs assigned mainly to monothalamids. The majority of them belong to brackish and marine taxa. The samples from the surface of the wetland are dominated by three freshwater foraminiferal MOTUs and one marine MOTU with a very low number of sequences. In old peat samples, the foraminiferal DNA is either not detected (HC4) or only represented by a single marine MOTU with a very small number of reads (HC5). Conversely, in the sand layers, we found 6 MOTUs that belong to marine (e.g., Epistominella sp. and Cylindrogullmia sp.) and brackish species (Haynesina). Five MOTUs are found in the younger sand layers, whereas one MOTU (Epistominella sp.) is present in the oldest analysed sediments (HC7).

\section{Discussion}

This proof-of-concept study demonstrates the occurrence of marine foraminiferal DNA in sandy sediment layers identified according to sedimentological and micropalaeontological criteria as palaeotsunami deposits. These deposits form layers comprised of coarse sand and gravel that are sharply separated from the neighbouring peat. The layers are thin and continuous over long distances (> $600 \mathrm{~m}$ inland) and become thinner landward. Moreover, there are visible subunits with grain size fining upward. These characteristics are considered typical for tsunami deposits, as storm-related deposits have 
typically much smaller lateral extent and consist of thicker laminated layers (Morton et al., 2007). The diatom assemblages in the sand layers reveal typical characteristics reported from tsunami deposits (Goff et al., 2012; Dura et al., 2016); they have a low number of diatom valves and include diatoms from various habitats, including marine species. The tsunami origin of these layers is further corroborated by previous studies that document the presence of two historical and at least fifteen palaeotsunami layers in coastal plains, wetlands and lagoons of eastern Hokkaido during the last 5,500 years (Nanayama et al., 2003, 2007; Sawai et al., 2009). They also recognised that nine of the palaeotsunamis were unusually large, the youngest of which was in the 17th century, shortly before the time of deposition of Ko-c2 and Ta-b tephras. We infer that our thickest and youngest palaeotsunami layer (T1) could be a record of the same event. The Urahoro wetland does not contain clear sedimentary evidence of younger and smaller tsunamis, for example the historical 1843 and 1894 AD events, and thus only the unusually large palaeotsunamis are preserved.

The preservation of marine foraminiferal DNA sequences is remarkable given the changeability of the studied coastal environment (marine inundation events, variable temperature, fluctuating groundwater table, etc.). Unsurprisingly, the samples from the modern beach and wetland contain more abundant and diversified foraminiferal DNA than the older sediments, likely due to the degradation of DNA with time. The MOTUs identified in the palaeotsunami sandy deposits are different from the MOTUs identified in the overlying modern peat, suggesting no downward leaching of DNA from the surface. Sand is commonly considered to be much less efficient for the adsorption of various compounds than clay minerals; however, there is evidence from laboratory experiments (e.g., Lorenz and Wackernagel, 1987) showing that silica sand is efficient in adsorption and thus in the protection of DNA. Nucleic acids bind to silica in high ionic strength aqueous solutions (e.g., 
in seawater). Therefore, it is probable that sand transported by a tsunami has DNA adsorbed on the grain surfaces.

The identification of marine foraminiferal DNA in palaeotsunami deposits in the absence of any micropalaeontological evidence facilitates the interpretation of sandy layers deposited in settings with a low preservation of carbonate microfossils. However, it also opens new opportunities for the identification of palaeotsunami records. First, DNA analyses increase the range of potentially indicatory species. Foraminifera include species that produce tests but also single-chambered (monothalamous) species without a mineral test, which normally are not preserved in the geological record. However, their DNA may be preserved, as in our study, where the palaeotsunami deposits and peat layers revealed marine and freshwater monothalamids species, respectively. Secondly, foraminiferal DNA is present not only within marine sediments but also in pore and bottom waters in the form of tiny propagules or extracellular DNA. Thus, marine DNA proxy may be considered similar to other geochemical signals of seawater and help to trace the maximum inundation limit, which often exceeds the limit of tsunami deposition (e.g., Chagué-Goff et al., 2012). For instance, we observed the very small number of reads of marine foraminiferal DNA in an old peat sample (HC5). It might be due to contamination (e.g. leaching, laboratory), but it may well represent a genuine signature of a former seawater inundation, which did not leave visible deposits.

Further studies are necessary to fully employ ancient sedimentary DNA as a tool to expand palaeotsunami records. These studies will need to address the small scale variability of DNA records, test various DNA extraction methods, assess in more detail problems of bioturbation, leaching, influence of pore water chemistry, as well as to apply the method also to other groups of organisms. In the present work we have focused on foraminifera as their few freshwater lineages are clearly identifiable from marine forms, which is not the case of 
other groups, for instance of diatoms. However, in view of our results, it is clear that the DNA of marine organisms may be preserved in sandy deposits under harsh coastal conditions for at least two millennia, even in the absence of any micropalaeontological evidence. The preservation of foraminiferal DNA in coastal zone sediments opens the possibility for applying ancient DNA in studies on coastal zone evolution, sea level changes, as well as may help to distinguish tsunami from storms deposits, since tsunami is expected to transfer DNA of species from deeper and more offshore environments (e.g. Uchida et al., 2010).

Acknowledgements. W.S. would like to thank the Hokkaido University in Sapporo for funding the fieldwork and for hosting his stay in Japan. K. Pleskot kindly assisted with the laboratory analyses. This work was supported by Swiss National Science Foundation (grant numbers 31003A-159709 and 316030-150817). We thank two anonymous reviewers for useful comments.

\section{Figure legends}

Figure 1. Study area. (a) General setting; the bold lines with triangles mark the seaward edges of subduction zones. (b) Location of the Urahoro study site on Hokkaido Island, with the marked local sources of tephra layers plotted in Fig. 2: Mt. Tarumai and Mt. Komagatake. (c) Locations of the sampling sites. Sediment core HC was used for the detail analyses. The elevation of the coastal dune is up to $5 \mathrm{~m}$ a.s.l. The source maps for (a) and (b) are from Google Earth.

Figure 2. Stratigraphy and tephra sources. (a) Simplified stratigraphy of the studied transect (Fig. 1). T1 to T5 denote the sandy palaeotsunami deposits. The tephra layers are assigned to 
particular eruption events on the basis of their appearance and chemistry. (b) Harker diagram of glass from the tephra layers with a marked field of chemical compositions for the regional major eruption type localities (Machida and Arai, 2003; Nakamura, 2016).

Figure 3. The results of the sedimentological, micropalaeontological and molecular analyses for sediment core $\mathrm{HC}$ and the reference modern peat and beach samples. The following are presented from left to right: organic matter content expressed as loss on ignition (LOI), weight content $<0 \Phi$ sediment fraction, mean grain size $>0 \Phi$ fraction, sediment sorting, contribution of marine and brackish diatoms, number of foraminiferal DNA sequences, number of foraminifera DNA MOTUs, fraction (\%) of the sum of marine and brackish foraminifera DNA sequences and freshwater sequences (the thicknesses of the bars show the relative amounts of DNA sequences), and sample codes. A* marks the samples that are poor in diatoms. The background colours as in Fig. 2.

\section{References}

Battarbee, R.D., 1986. Diatom analysis. In: Berglund B.E. (Ed.), Handbook of Holocene Paleoecology and Paleohydrology, John Wiley \& Sons, pp. 527-570.

Chagué-Goff, C., 2010. Chemical signatures of palaeotsunamis: a forgotten proxy? Marine Geology 271, 67-71.

Chagué-Goff, C., Andrew, A., Szczuciński, W., Goff, J., Nishimura, Y., 2012. Geochemical signatures up to the maximum inundation of the 2011 Tohoku-oki tsunami implications for the 869 AD Jogan and other palaeotsunamis. Sedimentary Geology $282,65-77$.

Coolen, M.J.L., Muyzer, G., Rijpstra, W. I. C., Schouten, S., Volkman, J. K., Damsté, J. S. S., 2004. Combined DNA and lipid analyses of sediments reveal changes in Holocene 
haptophyte and diatom populations in an Antarctic lake. Earth and Planetary Science Letters 223, 225-239.

Coolen, M.J.L., Orsi, W.D., Balkema, C., Quince, C., Harris, K., Sylva, S.P., FilipovaMarinova, M., Giosan, L., 2013. Evolution of the plankton paleome in the Black Sea from the Deglacial to Anthropocene. Proceedings of the National Academy of Sciences of the USA $110,8609-8614$.

Coolen, M.J.L., Overmann, J., 2007. 217 000-year-old DNA sequences of green sulfur bacteria in Mediterranean sapropels and their implications for the reconstruction of the paleoenvironment. Environmental Microbiology 9, 1099.

Dura, T., Hemphill-Haley, E., Sawai, Y., Horton, B. P., 2016. The application of diatoms to reconstruct the history of subduction zone earthquakes and tsunamis. Earth-Science Reviews 152, 181-197.

Esling, P., Lejzerowicz, F., Pawlowski, J., 2015. Accurate multiplexing and filtering for highthroughput amplicon-sequencing. Nucleic Acids Research 43, 2513-2524.

Goff, J., Chagué-Goff, C., Nichol, S., Jaffe, B., Dominey-Howes, D., 2012. Progress in palaeotsunami research. Sedimentary Geology 243-244, 70-88.

Hofmann, G., Werum, M., Lange-Bertalot, H., 2011. Diatomeen im Süßwasser-Benthos von Mitteleuropa. A.R.G. Gantner Verlag K.G.

Jaffe, B.E., Gelfenbaum, G., 2007. A simple model for calculating tsunami flow speed from tsunami deposits. Sedimentary Geology 200, 347-361.

Lange-Bertalot, H., 2000. In: Lange-Bertalot, H. (Ed.) Iconographia Diatomologica Annotated Diatom Micrographs_-Diatom Flora of Marine Coasts I vol. 7. Koeltz Scientific Books. 
Lejzerowicz, F., Esling, P., Majewski, W., Szczuciński, W., Decelle, J., Obadia, C., Arbizu, P.M., Pawlowski, J., 2013. Ancient DNA complements microfossil record in deep-sea subsurface sediments. Biology Letters 9, 20130283.

Lejzerowicz, F., Esling, P., Pawlowski, J., 2014. Patchiness of deep-sea benthic Foraminifera across the Southern Ocean: insights from high-throughput DNA sequencing. Deep Sea Research Part II: Topical Studies in Oceanography 108, 17-26.

Lorenz, M. G., Wackernagel, W., 1987. Adsorption of DNA to sand and variable degradation rates of adsorbed DNA. Applied and Environmental Microbiology 53, 2948-2952.

Machida, H., Arai, F., 2003. Atlas of Tephra in and Around Japan, revised ed. University of Tokyo Press, Tokyo (in Japanese).

Morton, R. A., Gelfenbaum, G., Jaffe, B. E., 2007. Physical criteria for distinguishing sandy tsunami and storm deposits using modern examples. Sedimentary Geology 200, 184207.

Nakamura, Y., 2016. Stratigraphy, distribution, and petrographic properties of Holocene tephras in Hokkaido, northern Japan. Quaternary International 397, 52-62.

Nanayama, F., Furukawa, R., Shigeno, K., Makino, A., Soeda, Y., Igarashi, Y., 2007. Nine unusually large tsunami deposits from the past 4000 years at Kiritappu marsh along the southern Kuril Trench. Sedimentary Geology 200, 275-294.

Nanayama, F., Satake, K., Furukawa, R., Shimokawa, K., Atwater, B.F., Shigeno, K., Yamaki, S., 2003. Unusually large earthquakes inferred from tsunami deposits along the Kuril trench. Nature 424, 660-663.

Naviaux, R.K., Good, B., McPherson, J.D., Steffen, D.L., Markusic, D., Ransom, B., Corbeil, J., 2005. Sand DNA - a genetic library of life at the water's edge. Marine Ecology Progress Series 301, 9-22. 
Pedersen, M.W., Overballe-Petersen, S., Ermini, L., Sarkissian, C.D., Haile, J., Hellstrom, M., Spens, J., Thomsen, P.F., Bohmann, K., Cappellini, E., Schnell, I.B., Wales, N.A., Carøe, C., Campos, P.F., Schmidt, A.M.Z., Gilbert, M.T.P., Hansen, A.J., Orlando, L., Willerslev, E., 2015. Ancient and modern environmental DNA. Philosophical Transactions of the Royal Society B: Biological Sciences 370, 20130383.

Pilarczyk, J. E., Dura, T., Horton, B. P., Engelhart, S. E., Kemp, A. C., Sawai, Y., 2014. Microfossils in coastal environments as indicators of paleo- earthquakes, tsunamis and storms. Palaeogeography, Palaeoclimatology, Palaeoecology 413, 144-157.

Pochon, X., Wood, S.A., Keeley, N.B., Lejzerowicz, F., Esling, P., Drew, P., Pawlowski, J., 2015. Accurate assessment of the impact of salmon farming on benthic sediment enrichment using foraminiferal metabarcoding. Marine Pollution Bulletin 100, 370382.

Randlett, M. È., Coolen, M. J.L., Stockhecke, M., Pickarski, N., Litt, T., Balkema, C., Kwiecien, O., Tomonaga, Y., Wehrli, B., Schubert, C. J., 2014. Alkenone distribution in Lake Van sediment over the last $270 \mathrm{ka}$ : influence of temperature and haptophyte species composition. Quaternary Science Reviews 104, 53-62.

Rawlence, N. J., Lowe, D.J., Wood, J.R., Young, J.M., Churchman, G.J., Huang, Y.T., Cooper, A., 2014. Using palaeoenvironmental DNA to reconstruct past environments: progress and prospects. Journal of Quaternary Science 29, 610-626.

Sawai, Y., Kamataki, T., Shishikura, M., Nasu, H., Okamura, Y., Satake, K., Thomson, K.H., Matsumoto, D., Fujii, Y., Komatsubara, J., Aung, T.T., 2009. Aperiodic recurrence of geologically recorded tsunamis during the past 5500 years in eastern Hokkaido, Japan. Journal of Geophysical Research 114, B01319. 
Somboonna, N., Wilantho, A., Jankaew, K., Assawamakin, A., Sangsrakru, D., Tangphatsornruang, S., Tongsima, S., 2014. Microbial ecology of Thailand tsunami and non-tsunami affected terrestrials. PLoS ONE 9, e94236.

Sugawara, D., Goto, K., Imamura, F., Matsumoto, H., Minoura, K., 2012. Assessing the magnitude of the 869 Jogan tsunami using sedimentary deposits: Prediction and consequence of the 2011 Tohoku-oki tsunami. Sedimentary Geology 282, 14-26.

Szczuciński, W., 2012. The post-depositional changes of the onshore 2004 tsunami deposits on the Andaman Sea coast of Thailand. Natural Hazards 60, 115-133.

Torti, A., Lever, M. A., Jørgensen, B. B., 2015. Origin, dynamics, and implications of extracellular DNA pools in marine sediments. Marine Genomics 23, 185-196.

Uchida, J.-I., Fujiwara, O., Hasegawa, S., Kamataki, T., 2010. Sources and depositional processes of tsunami deposits: analysis using foraminiferal tests and hydrodynamic verification. Island Arc 19, 427-442. 


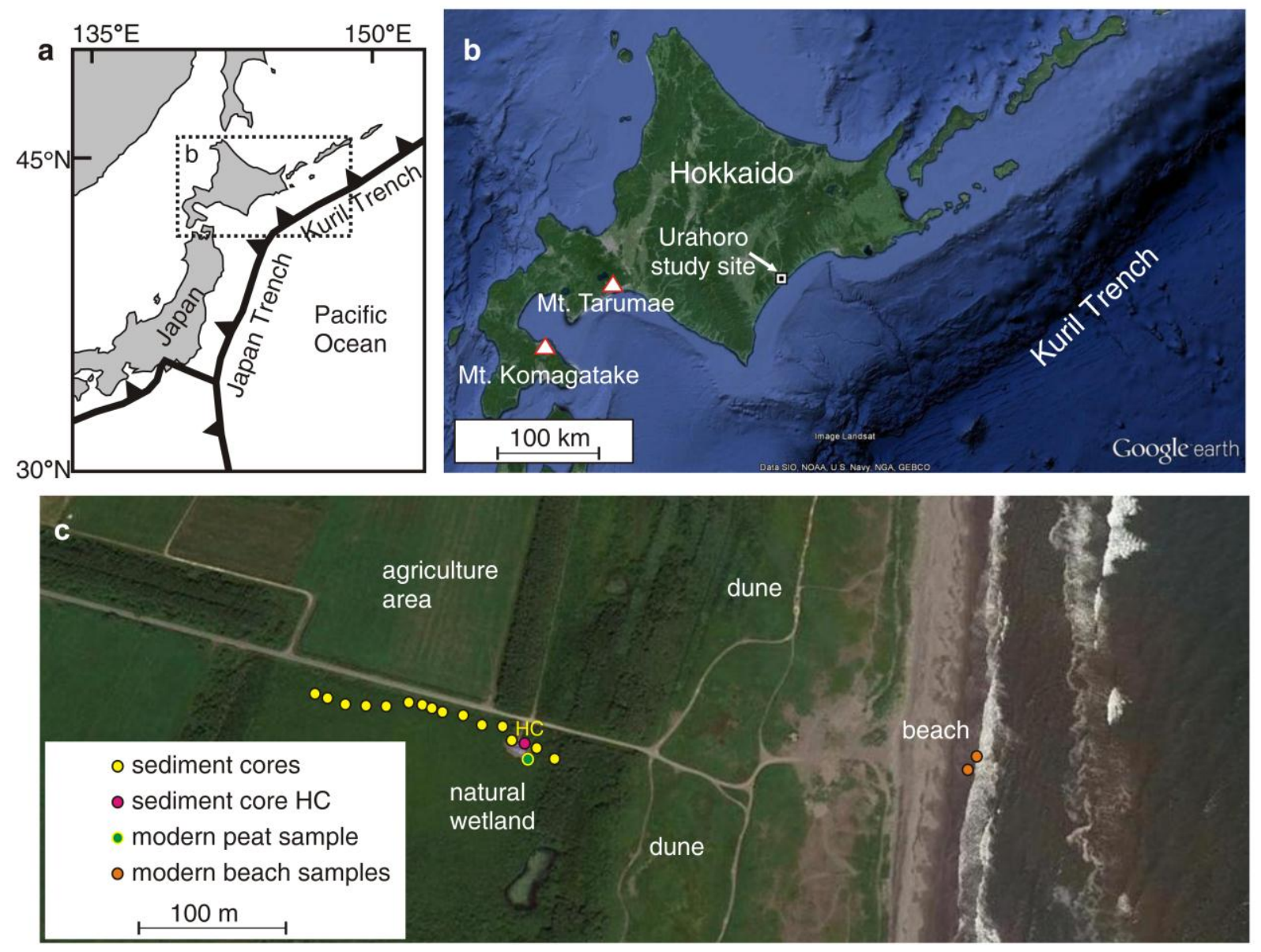


a

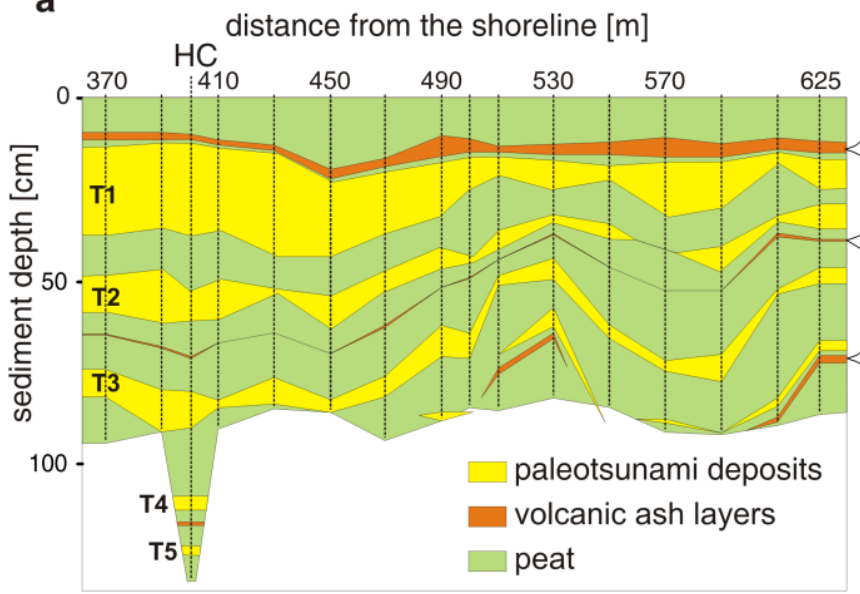

b

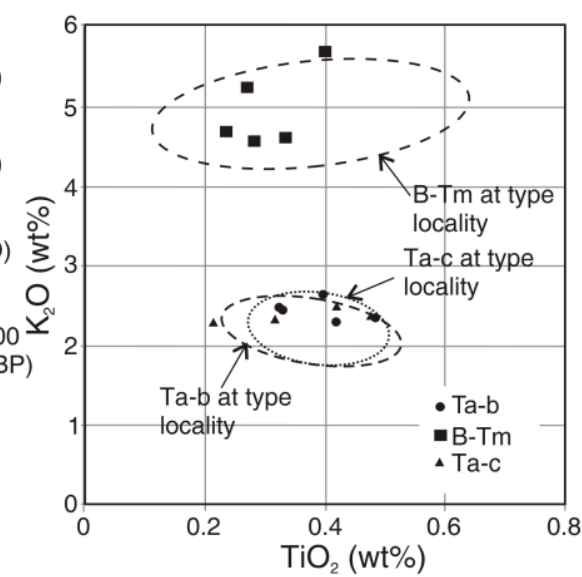




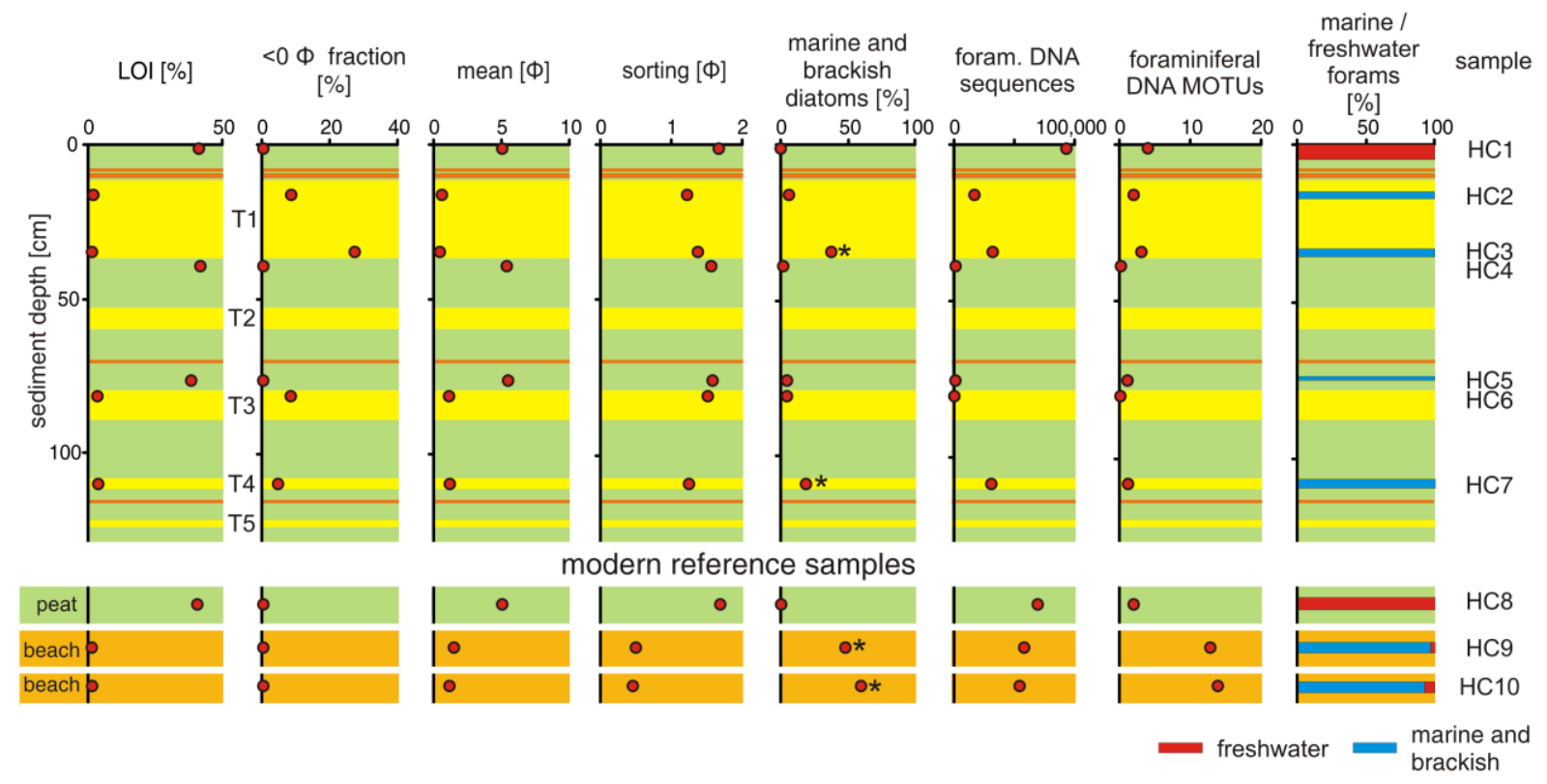

